\title{
DESCRIPTION OF ETHICAL PERCEPTION ABOUT CORRUPTION MEASURES IN YOUTH WHO HAVE PARENTS WITH CORRUPTION BEHAVIOR
}

\author{
Nanda Amelia ${ }^{1}$, Tia Rahmania ${ }^{1}$ and Mulia Sari Dewi ${ }^{2}$ \\ $\left\{\right.$ mulia.sari@uinjkt.ac.id $\left.{ }^{2}\right\}$ \\ Paramadina University, Jakarta, Indonesia 1 Jakarta Islamic State University, Indonesia ${ }^{2}$
}

\begin{abstract}
Ethical perception is a person's attitude in selecting information, regulating and interpreting meanings that are in accordance with the principles of truth and applicable in social norms which are generally not written. According to Allport's perception has three aspects, namely the cognitive component, the affective component, and the conative component. In principle, corrupt bahavior is a behavior related to abuse of authority and violation of laws, norms, and morals for the benefit of personal gain or for other people. This study uses a qualitative approach to the type of case study research. The sampling technique in this study was purposive sampling. The method used in data collection is interviewed with semi-structured interviews. This study consists of one subject who was a teenager who had corruptors as parents with two informants. The results of this study indicate that it is ethical to say that the subject parent bribes even indirectly. The subject also perceives that the nominal given by his parents to bribe the judge includes a small nominal and the ethical conduct of bribery with a large nominal value. The subject's ethical perception is also influenced be his parents
\end{abstract}

Keywords: Perception, ethical perception, corruption behavior, adolescents

\section{Introduction}

Corruption is a phenomenon that often occurs in Indonesia which always attracts attention and invites public opinion. Problems about corruption are being discussed by the public, especially in the mass media both locally and nationally [6]. Based on the results of data on investigations of corruption cases in Indonesia in the past four years, in 2014 there were 56 corruption cases investigated by the KPK. Then it rose in 2015 to 57 cases, and in 2016 it rose again to 99 cases. Based on data, until September 30, 2017 there were 78 investigations of corruption cases [13]. According to the Corruption Perceptions Index 2017 Indonesia is ranked 96th in the world with a country that commits corruption [25].

Etymologically, the term "corruption" comes from Latin, which is "corruption" or "corruptus" which means bad, bad, cheating, can be bribed, immoral, deviates from purity, violates religious, mental, and legal norms [22]. Corruption as behavior that deviates from 
the official duties of a state office because of gains in status or money relating to the person (individual, close family, own group) or violating the rules for implementing some personal behavior [5]. Corrupt practices were carried out in a closed manner because they relied on secrecy, collusion and little trust so that illicit transactions did not leak out [3]. Lalu Purwantari said that the practice of corruption is no longer limited to structural crime and moral violations, but more than that, corruption has created a banality of corruption aa. Banal, the same as making corruption as something normal, ordinary, reasonable, even becoming the driving principle of everyday life. Corruption has taken root and tends to be accepted by many people [19]. In addition, corruption will have a negative impact on political, economic and social development. There are two types of corruption, namely bureaucratic corruption (the majority of corruptors are employees or small bureaucrats) and political corruption (perpetrators of corruption in politicians in parliament, high officials in government, and law enforcers in and on outside the courthouse) [1]. Alkostar defines political corruption by someone who has a political position, including the president, ministers, governors, regents and mayors, members of parliament, commissioners, and others [1].

Throughout 2015 researchers found five politicians who were entangled in corruption cases [2], the researchers raised one case of alleged granting bribes to judges carried out by the former Governor of North Sumatra, namely the GPN and dragging ES who is a young wife of GPN [15]. GPN is entangled in four cases of bribery, but researchers will focus on cases of GPN and ES bribery against Medan PTUN judges [12]. This is also supported by the results of the pre-eliminary interview conducted by researchers in which the subject said,

"So, Sis, in 2015 when I was first arrested because of the alleged bribery case, even though my father had never been questioned, never been questioned, there was never procedural-procedural, but I just wanted to leave the arrest letter until my mom was in a mess and finally asked assistance to one of the lawyers with the initials OK. Actually giving money all the things for that thing is normal until the trial is requested. Asked for the money to make money and lawyers. But it turned out that the money was played with the lawyers' subordinates and instead bribed the judges so the point was mommy and daddy or nothing was trapped. Because the money is from mom, too, so my mom joined in because of the source of the funds."

(Z, Interview Results, May 24, 2018).

From the pre-eliminary results, $Z$ revealed that the news in the media was incorrect because the media did not know the real problem. The subject also perceived that the nominal given by his parents to bribe the judge was small and not included in bribery. The arrest and detention of the subject's parents had an impact on Z. One of the people affected by corruption was the family of perpetrators of corruption and also had an impact on the children of perpetrators of corruption [6]. This study focuses on the subject of adolescents who are admitted to the hospital because they hold shame and do not want to leave the house and do not want to go to school first. This is supported by the pre-eliminary conducted by researchers to the subject and found that,

"Ohhh ... after I knew about this case, it definitely has an effect on me anyway ... I was just embarrassed and imagine what if my friends knew that my parents were afraid to be bullied so, I was so stressed that I got sick, I was really down and I feel lazy to go out of the house or to even go to school. I was also always thinking what if I live far from my parents."

(Z, Interview Results, April 4, 2018). 
From the results of the interview the subject revealed that the effect of the case of his parents had an impact on the subject himself, namely the subject felt embarrassed, did not dare to go to school because of the fear of being bullied, and stress which resulted in becoming sick. Adolescence is a time of turmoil and problems [7]. At this time a person experiences physical and mental changes drastically. Adolescence is a difficult time [20]. Not only the difficulties for the individual concerned, but also for his parents, and the community. Furthermore, the researcher also conducts a pre-eliminary related to the subject's ethical perceptions of acts of corruption committed by both parents of the subject where the subject says,

"If according to my perception, the nominal value of my parents through lawyers is small, because actually there are still many cases that doest disclose related to bribing a judge with a big nominal ... the ethics is if you want to bribe the judge, its all right and it is safe, and, if the bribe is so good for the size of the judge, it is like getting it very easily... my parents also say that if it is so small, how come? Only my parents just got hit. I also agree with my parents' words. " (Z, Interview Results, May 24, 2018).

From the pre-eliminary results the subject said that in fact there were still many cases of bribery to judges with a number greater than nominal that the subjects parents gave through their lawyers and the parents of the subjects were unlucky because the bribery was revealed. The subject also perceives if the nominal case of his parents is small. The subject also said that each individual has their own perceptions related to responding to something as well as subjects who have their own perceptions of bribery cases that ensnare their parents that legally their parents are indeed bribery. A person's courage in dealing with corruption is very much determined by his moral philosophy. Personal moral philosophy is very important to make judgements and ethics [3]. Thus the subject has his own ethical perception regarding the acts of corruption committed by his parents.

Every individual has their own thoughts to perceive something. Perception is an activity of the senses that provides an assessment of physical objects and social objects [26]. The process of perception begins when the stimulus about the senses and then the stimulus is then forwarded by the nerves, namely the brain. In the brain then a process occurs so that the individual produces perception. Perceptions are influenced by factors of experience, learning processes, and knowledge [18]. The term perception is often equated with opinion; this is because in perception there is an interpretation of one's views or opinions. Perception is an important function for an individual in making decisions because perception becomes the basis for individuals to form identification, analysis, and ultimately can conclude the meaning of a stimulus. Perception results are one of the important considerations in making decisions. Factors that influence perceptions are internal factors, external factors, the existence of someone's past experience, someone's expectations where it is included in personal factors, then there are also situational factors. Perception is an experience of the object of events or relationships obtained by deducing information and interpreting the message [17]. A person's perception of good and bad is limited by ethical existence.

Ethics is behavior that is carried out in accordance with social norms that are generally accepted by the community as related to right and good actions [27]. Besides that, there are ethics that can influence behavior and ethics whether or not decisions are made. Ethical perceptions are moral perceptions that are instilled in individuals who form a philosophy of morality and are generally unwritten [15]. Every individual has his own way of doing things in his life. So from that individual also has their choice based on the individual's ethical perceptions. At present there are no similar studies with the variables to be studied, 
namely the description of ethical perceptions of acts of corruption in adolescents who have parents of corrupt actors but researchers found several studies on ethical perceptions, research shows that perceptions Ethics can occur when a situation is seen as an acceptable part [10]. Many people who carry out an action are due to one's own ethical perception. Then another study showed that ethical perceptions cannot be distinguished only by looking at the GPA (Grade Point Average) but also need to be seen from student personality factors such as the surrounding environment, personal experience, habits, and also the norms adopted by someone [24].

Based on the explanation, further interest arose towards the subject to find out how the ethical perceptions of acts of corruption in adolescents who have parents who are perpetrators of corruption.

\section{Methodology}

In this study, the qualitative research model that will be used by researchers is a case study (case study) which is a detailed qualitative research model of individuals or studies of certain social units over a period of time. Case studies are also comprehensive, intense, detailed in depth and more directed as an effort to examine problems or phenomena that are contemporary in nature. The reason researchers use the case study model is because basically the nature of the case study is deep and detailed, so that when associated with this research is to understand in depth about the concept of ethics in adolescents who have parents of perpetrators of corruption. The researcher used an intrinsic case study with the aim of better understanding and detailing the phenomenon of this research.

\subsection{Research subject}

The research subject is an individual or group of individuals as the main actor in qualitative research conducted, while th e researcher only functions as a photographer who is tasked with photographing everything the research subject researched and explored [4, $13]$.

In this study, researchers involved one subject, namely a 17-year-old boy with the initials " $Z$ ". $Z$ is the youngest of two children, $Z$ has one older sister. $Z$ admitted that he was close to his brother, grandmother, and grandfather. Since childhood, the subject's mother has become accustomed to working to make a living so she often stays with her older siblings, grandmothers and grandparents. The subject is a student in one of the high schools in Bintaro area. In addition, the subject also likes to spend time with his friends. Z is a spoiled, smart, sensitive, friendly, sociable, and loyal friend, $Z$ is known as a pleasant person. $\mathrm{Z}$ became a friend favoured by his friends.

\begin{tabular}{|l|l|l|}
\hline NO & Biodata & Z subject \\
\hline 1. & $\begin{array}{l}\text { Date of } \\
\text { birth }\end{array}$ & $\begin{array}{l}\text { Jakarta, December } 12, \\
2001\end{array}$ \\
\hline 2. & Age & 17 years \\
\hline 3. & Gender & Man \\
\hline
\end{tabular}




\begin{tabular}{|l|l|l|}
\hline 4. & Religion & Islam \\
\hline 5. & Tribes & Sunda \\
\hline 6. & Birth order & $\begin{array}{l}\text { Second child by } \\
\text { siblings }\end{array}$ \\
\hline 7. & $\begin{array}{l}\text { Last } \\
\text { educa } \\
\text { tion }\end{array}$ & Junior high school \\
\hline 8. & Status & Single \\
\hline 9 & Work & Student \\
\hline 10. & Residence & bintaro \\
\hline
\end{tabular}

Table 2.2 Demographic Data of Research Subjects

\section{2. 1 Source: Researcher, 2018}

\section{Reasearch informant}

In this study the researcher involved two informants. The researcher chose informants in this study based on recommendations from the subject, namely initials $\mathrm{I}$ and $\mathrm{R}$. Informants in this study amounted to two people. The informant is the sibling of the subject and the husband of his sibling / sister-in-law who is familiar with and has a close relationship with the subject.

The first informant with the initials I was 23 years old. This informant is the sibling of the research subject. I was a student at one of the private universities in the South Jakarta area. At this time I was married and was pregnant so I decided to take a break from college. I still live with the subject at the home of the subject's parents. I is also a person whose subject believes in telling stories and complaining. Then the second informant with the initials $\mathrm{R}$ is 26 years old. Currently, $\mathrm{R}$ works as an Indonesian language teacher at a State Vocational School in South Jakarta. $\mathrm{R}$ is the husband of the first informant.

$\mathrm{R}$ is one person who is close to the subject because $\mathrm{R}$ helps accompany and take care of the needs of the subject and siblings of the subject. This $\mathrm{R}$ informer recognized the subject well because $\mathrm{R}$ had a relationship with the siblings of the subject since the subject's parents were involved in a case of alleged corruption.

Table 2.2.2 Demographic Data from Research Informants

\begin{tabular}{|c|l|l|l|}
\hline No. & Biodata & Informant Z & Informant Z \\
\hline 1. & Initial & I & $\mathrm{R}$ \\
\hline 2. & $\begin{array}{l}\text { Date of } \\
\text { birth }\end{array}$ & $\begin{array}{l}\text { Bandung } \\
\text { April,1995 }\end{array}$ & $\begin{array}{l}\text { Sukabumi, } \\
\text { February 9, } \\
1992\end{array}$ \\
\hline 3. & Age & 23 years old & 26 years old \\
\hline
\end{tabular}




\begin{tabular}{|c|l|l|l|}
\hline 4. & Gender & Female & Male \\
\hline 5. & Religion & Islam & Islam \\
\hline 6. & Tribe & sunda & Sunda \\
\hline 7. & Work & House wife & Teacher \\
\hline 8. & Residence & Bintaro & Bintaro \\
\hline
\end{tabular}

\section{2. 3 Source: Researcher, 2018}

\section{2. 4 Method of collecting data}

In this study, researchers used data collection methods in the form of interviews. This method will produce extensive, complete and in-depth data, making it easier for researchers to interpret the results of researchers.

\section{Research result}

The results showed that the perception of subjects who had parents who are corruptors was because the subjects had their own views and information regarding corruption cases that ensnared the parents of both subjects. This is supported by the statement put which reveals that the factors that influence perception are as follows: selective attention, excitatory characteristics, individual values and needs, and prior experience [11]. The subject had a perception that was influenced by his parents' view that it was unethical if his parents were declared entirely guilty of a judge's bribery case because the nominal bribe was small.

Based on the explanation of the results of the research on information about the case of the subject's parents regarding corruption cases, their parents perceive that the subject's parents indirectly made bribery against the judge. The statement is said to be an ethical subject because there is evidence. It was revealed that the parents of the subject were proven to have carried out bribery carried out by ES against the judge as a public official for the benefit of his case. Bribery usually occurs from misuse of public official authority [16]. The subject perceived that the money used to bribe the judge, namely nominal one hundred and fifty million including a small nominal and not included in the category of bribery and supposed to bribe the judge needed a large nominal rather not found out. If the gift included in the small nominal is donation and the informant also states the same thing with the subject.

In reality the bribery case of either the recipient or the giver in any amount is still included as an act of corruption [16]. The subject reveals that the bribery party will get a number of benefits. This is supported by the statement that bribery corruption will provide material benefits personally and to the authorities [8]. The statement of the subject is also based on information received by the subject in which all information is able to be processed in such a way in accordance with cognitive development as a teenager. Adolescence is 2011 experiencing a rapid development in intellectual / cognitive aspects $[21,4]$. Based on the explanation of information about the case of parents including the 
cognitive component of the subject that is arranged on the basis of knowledge or information possessed by the subject. This knowledge will form a belief [14].

Based on information about the subject's feelings related to acts of corruption committed by his parents, the subject had felt emotional when he found out his parents were named as suspects in a bribery case against the judge. The subject was annoyed at the media coverage that cornered his parents because according to the perception of the subject media coverage was not in accordance with what actually happened. The subject also said that he had been bullied by his friends at school to make the subject sick, embarrassed, and reluctant to go to school. This is in line with the research that if someone commits a criminal act of corruption, surely it will have an impact on his family's life [6]. Lazarus added that the changes experienced by adolescents belong to emotional and behavioral responses [6]. Emotional response is in the form of fear, anxiety, shame, anger and so on. While the behavior response is in the form of withdrawal from the surrounding environment. The subject perceived that actually there were still many cases of bribery against the judge, but not all of them were revealed and the subject revealed that this was unfair to him. This is supported by the statement that bribery is an iceberg phenomenon, which is only a small part of which is revealed even though many cases of bribery are not revealed [8]. The informant said that the subject was upset and angry so he had coping by smoking, drinking alcohol, and playing with his closest friends as a way to get rid of emotions. Informant perceives this as a natural thing because this subject is still a teenager and is still unstable so the informant only monitors and advises if it has gone too far. This is in line with the opinion that adolescence is a period full of turmoil and problems and experiences drastic mental changes [7]. Associated with this feeling usually tends to be more experienced by adolescents especially if they are facing a difficult situation [4]. Based on information about this feeling included in the affective component proposed by Allport that this affective aspect is related to pleasure and displeasure and is evaluative and relates to the value system possessed by adolescents related to the case of their parents[14].

Judging from the information about the attitude of the subject about corruption cases that ensnare both parents that the subject has a perception if his parents are being mocked by other parties so that the bribery case stumbles. The subject perceives that his parents are good people so it is impossible to do the bribery. The subject also could not accept the words of other people who cornered his parents so that the subject could not hold back his emotions. The subject perceives unethical if his parents are said to be entirely guilty and exposed because the subject's parents are public officials. The subject also said that law enforcers should carry out their duties in accordance with their procedures and not accept bribes even though ethically the law enforcers were still the target for bribery. The subject also stated that all those who bribe the judge of the case must disclose for the sake of justice. The subject's statement got from his parents. According to Dougall the subject's ethical perceptions belong to situational factors because they come from outside the subject but the subject is also involved in a group [28]. This is because the subject's ethical perceptions are influenced by his parents so that the subject also tends to follow the ethical thinking of his parents. The subject revealed that ethically a person is willing to accept bribes because of a factor of economic loss or being pressured by circumstances. This is supported by a statement that one of the factors a person is willing to accept bribes is due to weak socio-economic conditions so that one's motivation to maintain life [23]. The informant also explained that what was absorbed by the subject was ethical because the subject was still a teenager so he still could not have his own thoughts. Thinking of adolescents is able to integrate themselves into adult societies [4]. Meanwhile, the 
informant also agreed that in fact the parents of the subject were slandered and unethical if they were declared completely wrong.

The informant also agreed that many cases of bribery against judges were not disclosed and nominally more than the subject parents gave. The informant also said that it was ethical if the subject had hit the friend who bullied him in the hope that his friend would deter and not carry out bullying again and as a form that the subject defended his parents, which he said was vilified. Psychological development of adolescents in the social role section is said that adolescents have conflicts that can cause emotional turmoil [21]. Teenagers are tasked to choose their own path; this is because teenagers know dangerous moments. Nevertheless, informants will also keep an eye on the subject's behavior. This is supported that adolescence is a period of difficulty [20]. This is because the transition period is a period of transition from children to adults. This situation creates a conflict that causes behavior that must be controlled frequently. Based on information about this attitude included in the conative component proposed by Allport which is a person's readiness to behave in relation to the object of his attitude [14].

Based on the presentation of the subject regarding the above components, it can be said that the subject has its own ethical perceptions of the bribery corruption case that ensnares the parents. The subject's ethical perception is that legally the subject's parents make bribery against the judge even though not directly. Then the subject perceived that the nominal for bribing the judge given by his parents was included in a small nominal and unethical if it was said to be bribery and his ethical conduct of bribery with a nominal of more than three hundred million. The subject also said that the ethics targeted by bribery were judges. This is in line with the opinion that the target of corruption in bribery of corruptors is law enforcement officers who examine and handle their cases because they avoid themselves from legal sanctions that will be imposed on them [8]. The subject also has an ethical perception that is also influenced by the words and thoughts of his parents and closest friends. This is in accordance with the statement that similarities in ethical perceptions can occur when a situation is seen as an accepted part [10].

\section{Conclusion}

Judging from the cognitive component, it is believed that the parent of the subject is indeed carrying out bribery even if not directly, this is because the source of money comes from his parents and there is evidence. The subject also perceived that the nominal bribe given to the subject's parents to the judge included a small nominal. The subject perceived that there were still many cases of bribery to the judge who were not revealed. Based on the affective component regarding parental cases, it was found that the subject felt some emotions and got bullying from his friends which made the subject unable to resist his emotions because the subject had the opinion that people who bully did not know in detail about the case of their parents and defended the subject towards his parents. The subject perceives that this is reasonable because the subject perceives that by doing so he will not get bullied any more and this is also taught by the informant because the subject is still a teenager so that he still has high emotional turmoil. Then in terms of the subject's conative components, it was found that the subject felt insecure about being distanced by his friends. The subject also perceives that it is unethical if his parents are declared completely guilty so that the subject is angry with others who blame his parents. 


\section{References}

[1] Abidin, Z., \& Siswadi, A. (2015). Psikologi Korupsi. Bandung: Remaja Rosdakarya.

[2] Ali, M., \& Asrori, M. (2011). Psikologi Remaja - Perkembangan Peserta Didik. Jakarta: Sinar Grafika Ofset.

[3] Awaludin, A. (2016). Ideologi Etis Penyingkap Birokrasi. Pandecta, 189 - 201.

[4] Creswell, J. (2009). Research Design Qualitative, Quantitative and Mixed Methods Approaches. United States of America: SAGE Publications.

[5] Fazzan. (2015). Korupsi di Indonesia Dalam Perspektif Hukum Pidana Islam. Jurnal Ilmiah Islam Futura, 146-165.

[6] Graydison, B. A., \& Budiani, M. S. (2013). Dampak Perilaku Korupsi ditinjau dari Stres pada Keluarga di Kabupaten Lombok Timur Selong - Nusa Tenggara Barat (NTB). Character , 1 $-6$.

[7] Gunarsa, S., \& Gunarsa, S. (2012). Psikologi Remaja. Jakarta: Libri.

[8] Haryadi, S. (2015). Reinterpretasi Tindak Pidana Korupsi Suap oleh Penegak Hukum dalam Perspektif Islam. Al-Adalah, 541-552.

[9] Herdiansyah, H. (2013). Wawancara, Observasi, dan Focus Groups. Jakarta: PT RajaGrafindo Persada.

[10] Ho, J. (2012). Ethical Perception: Are Differences Between Ethic Group Situation Dependent. Business Ethics: A European Review.

[11] Irwanto. (2002). Psikologi Umum : Buku Panduan Mahasiswa. Jakarta: PT Prenhallindo.

[12] Khabibi, I. (2015, November Selasa). Quattrick Kasus Korupsi Gatot Pujo Nugroho. Diambil kembali dari detiknews: https://m.detik.com/news/berita/3061252/quattrick- kasus-korupsigatot-pujo-nugroho

[13] Larasati, W. (2017, Desember 9). Kasus Korupsi di Indonesia dalam 3 Tahun Terakhir. Diambil kembali dari http://news.liputan6.com: http://news.liputan6.com/read/3190046/kasus- korupsi-di-indonesia-dalam-3-tahun-terakhir

[14] Mar'at. (1991). Sikap Manusia, Perubahan, serta Pengukurannya. Jakarta: Ghalia Indonesia.

[14] Movanita, A. (2015, Juli 28). KPK Tetapkan Gubernur Sumut dan Istrinya sebagai Tersangka. Diambil kembali darinasional.kompas.com: https://nasional.kompas.com/read/2015/07/28/18192 831/KPK.Tetapkan.Gubernur.Sumut.dan.Istrinya.sebagai.Tersangka

[15] Mulawarman, A. D., \& Ludigdo, U. (2010). "Metamorfosis Kesadaran Etis Holistik Mahasiswa Akuntansi: Implementasi Pembelajaran Etika Bisnis dan Profesi berbasis Integrasi IESQ" dalam Simposium Nasional Akuntansi XIII. Jurnal Akuntansi Multiparadigma, 421436.

[16] Pande, Y. (2011). Kebijakan Formulasi Tindak Pidana Suap dalam Bidang Politik. Jurnal Law Reform, 100- 128.

[17] Rakhmat, J. (2005). Psikologi Komunikasi. Bandung: Rosdakarya.

[18] Robbins, S., \& A. Judge, T. (2008). Essential of the Organizational Behavior. Edisi 9. New Jersey: Pearson Education.

[19] Salama, N. (2014). Motif dan Proses Psikologius Korupsi. Jurnal Psikologi, 149-164.

[20] Sarwono, S. (2012). Pengantar Psikologi Umum. Jakarta: Rajagrafindo Persada.

[21] Sarwono, S. W. (2007). Psikologi Remaja. Jakarta: Rajagrafindo Persada.

[22] Srinita. (2016). Strategi Menihilkan Korupsi di Sektor Pendidikan dan Kesehatan. Jurnal Politik, 1-12.

[23] Suhendi, C., \& Zaenuddin. (2015). Analisis Survey Faktor-Faktor yang Mempengaruhi Tindak Pidana Korupsi Aparat Pemerintah Daerah dan Pencegahannya di Provinsi Jawa 
Tengah. Jurnal Akuntansi Indonesia, 51-65.

[24] Theresia. (2018). Analisis Persepsi Etis Mahasiswa Akuntansi Mengenai Pelaporan Keuangan. Yogyakarta: Universitas Sanata Dharma.

[25] TRANSPARENCY INTERNATIONAL. (2018, Februari 21). Corruption Perceptions Index 2017. Diambil kembali dari http://www.transparency.org: https://www.transparency.org/news/feature/corruption_perceptons_index_27

[26] Walgito, B. (2004). Pengantar Psikologi Umum. Yogyakarta: Andi Offset.

[27] Widiastuti, E., \& Nugroho, M. A. (2015). Pengaruh Orientasi Etis, Equity Sensitivity, dan Budaya Jawa Terhadap Perilaku Etis Auditor pada Kantor Akuntan Publik di Yogyakarta. Jurnal Nominal, 32 - 48.

[28] Zulfahmi. (2005). Analisa Faktor-Faktor Yang Mempengaruhi Sikap dan Perilaku Etis Akuntan Publik di Kota Banda Aceh. Skripsi, Universitas Syiah Kuala. 